\title{
Results of case-control study of leukaemia and lymphoma among young people near Sellafield nuclear plant in West Cumbria
}

\author{
Martin J Gardner, Michael P Snee, Andrew J Hall, Caroline A Powell, Susan Downes, John D Terrell
}

Abstract

Objective-To examine whether the observed excess of childhood leukaemia and lymphoma near the Sellafield nuclear plant is associated with established risk factors or with factors related to the plant.

Design-A case-control study.

Setting-West Cumbria health district.

Subjects-52 Cases of leukaemia, 22 of nonHodgkin's lymphoma, and 23 of Hodgkin's disease occurring in people born in the area and diagnosed there in 1950-85 under the age of 25 and 1001 controls matched for sex and date of birth taken from the same birth registers as the cases.

Main outcome measures-Antenatal abdominal $x$ ray examinations, viral infections, habit factors, proximity to and employment characteristics of parents at Sellafield.

Results-Expected associations with prenatal exposure to $x$ rays were found, but little information was available on viral illnesses. Relative risks for leukaemia and non-Hodgkin's lymphoma were higher in children born near Sellafield and in children of fathers employed at the plant, particularly those with high radiation dose recordings before their child's conception. For example, the relative risks compared with area controls were 0.17 (95\% confidence interval 0.05 to 0.53 ) for being born further than $5 \mathrm{~km}$ from Sellafield $2.44(1.04$ to 5.71$)$ for children of fathers employed at Sellafield at their conception, and $6.42(1.57$ to 26.3$)$ for children of fathers receiving a total preconceptual ionising radiation dose of $100 \mathrm{mSv}$ or more. Other factors, including exposure to $x$ rays, maternal age, employment elsewhere, eating seafood, and playing on the beach did not explain these relationships. Focusing on Seascale, where the excess incidence has predominantly been reported, showed for the four out of five cases of leukaemia and one case of nonHodgkin's lymphoma whose fathers were employed at Sellafield and for whom dose information was obtained that the fathers of each case had higher radiation doses before their child's conception than all their matched control fathers; the father of the other Seascale case (non-Hodgkin's lymphoma) was not employed at the plant. These results seem to explain statistically the geographical association. For Hodgkin's disease neither geographical nor employment associations with Sellafield were found.

Conclusions - The raised incidence of leukaemia, particularly, and non-Hodgkin's lymphoma among children near Sellafield was associated with paternal employment and recorded external dose of whole body penetrating radiation during work at the plant before conception. The association can explain statistically the observed geographical excess. This result suggests an effect of ionising radiation on fathers that may be leukaemogenic in their offspring, though other, less likely, explana- tions are possible. There are important potential implications for radiobiology and for protection of radiation workers and their children.

\section{Introduction}

There has been concern about levels of childhood cancer around nuclear installations in the United Kingdom since 1983, when a Yorkshire Television programme (Windscale: the Nuclear Laundry) suggested that there was an excess of leukaemia near Sellafield. Several studies have been carried out since, and the one reported here was a direct consequence of a recommendation of the Black committee (of which MJG was a member). ${ }^{2}$ This investigation was a casecontrol study of leukaemia and lymphoma among young people in West Cumbria specifically asking whether known causes or factors associated with the nuclear site might have been responsible for the observed excess.

\section{Methods}

The design of the study, methods of data collection, and basic information are described in detail in the accompanying paper (p 429). ${ }^{3}$ Essentially all identified cases of leukaemia and lymphoma among people born in West Cumbria and diagnosed there at ages under 25 during 1950-85 were compared with controls matched by sex and date of birth selected-both unmatched (area controls) and matched (local controls) for civil parish of residence-from the same birth register into which the case's birth was entered. For both types of control up to eight controls were included in the analysis for each case, some of whom were both area and local controls. Comparisons were carried out using data from birth and medical records, from questionnaires to parents of cases and controls, and from employment and radiation records held by British Nuclear Fuels.

The analysis was carried out within the sets of cases and area or local controls, and findings are presented as relative risks with confidence intervals. The results were calculated using conditional logistic regression analysis, ${ }^{4}$ which produces estimates of odds ratios that approximate closely to relative risks, with the computer program EGRET. ${ }^{5}$ Unless otherwise stated the relative risks are for presence compared with absence of each factor; where specifically mentioned in tables relative risks are for the first compared with the second grouping, except in ionising radiation dose categories, where the risks are relative to the unexposed group.

\section{Results and comment}

Findings are shown for leukaemia alone and for leukaemia and non-Hodgkin's lymphoma combined (see accompanying paper) for area and local controls 
separately. Because some controls, who were entered closely adjacent to a case in the birth register, were both area and local controls these two analyses by control type were not completely independent statistically-for example, for the 52 leukaemia cases there were 217 area only controls, 207 local only controls, and 140 who were both (see table III of accompanying paper ${ }^{3}$ ). Results for non-Hodgkin's lymphoma are presented here only in combination with leukaemia for the reasons given in the accompanying paper and because the numbers were smaller. Numbers of individuals included in the analyses for different factors varied with the availability of data, and the number of case-control sets is given by the total number of cases. Results for Hodgkin's disease are not given in detail as they did not show any important associations with analysed factors in the same way as leukaemia and nonHodgkin's lymphoma.

ANTE-NATAL X RAYS

Table I shows relative risks for leukaemia and non-Hodgkin's lymphoma associated with maternal

TABLE I - Numbers of cases and controls with relative risks for leukaemia and non-Hodgkin's lymphoma in children by maternal exposure to abdominal $x$ rays in pregnancy according to medical records and questionnaires

\begin{tabular}{|c|c|c|c|c|c|c|c|}
\hline \multirow[b]{2}{*}{$\begin{array}{l}\text { Source of } x \text { ray } \\
\text { information }\end{array}$} & \multirow[b]{2}{*}{$\begin{array}{l}\text { Type of } \\
\text { control }\end{array}$} & \multicolumn{2}{|c|}{ Cases } & \multicolumn{2}{|c|}{ Controls } & \multirow[b]{2}{*}{$\begin{array}{l}\text { Relative } \\
\text { risk }\end{array}$} & \multirow{2}{*}{$\begin{array}{c}95 \% \\
\text { Confidence } \\
\text { interval }\end{array}$} \\
\hline & & Total & $\begin{array}{l}\text { No exposed } \\
\text { to } x \text { rays }\end{array}$ & Total & $\begin{array}{l}\text { No exposed } \\
\text { to } x \text { rays }\end{array}$ & & \\
\hline \multicolumn{8}{|c|}{ Leukaemia } \\
\hline \multirow[t]{2}{*}{ Medical records } & Area & 20 & 3 & 116 & 15 & $1 \cdot 15$ & 0.31 to 4.28 \\
\hline & Local & 20 & 3 & 109 & 13 & $1 \cdot 21$ & 0.31 to 4.66 \\
\hline \multirow{2}{*}{ Questionnaire } & Area & 35 & 4 & 116 & 9 & 1.74 & 0.44 to 6.82 \\
\hline & Local & 34 & 4 & 104 & 11 & $1 \cdot 19$ & 0.33 to 4.31 \\
\hline \multicolumn{8}{|c|}{ Leukaemia and non-Hodgkin's lymphoma } \\
\hline \multirow[t]{2}{*}{ Medical records } & Area & 28 & 5 & $167^{\circ}$ & 25 & $1 \cdot 19$ & 0.43 to 3.32 \\
\hline & Local & 28 & 5 & 153 & 20 & $1 \cdot 34$ & 0.46 to 3.88 \\
\hline \multirow[t]{2}{*}{ Questionnaire } & Area & 47 & 5 & 152 & 14 & $1 \cdot 32$ & 0.43 to 4.08 \\
\hline & Local & 45 & 5 & 143 & 15 & $1 \cdot 14$ & 0.37 to 3.53 \\
\hline
\end{tabular}

TABLE II - Numbers of cases and controls with relative risks for leukaemia and non-Hodgkin's lymphoma in children by some suspected risk factors

\begin{tabular}{|c|c|c|c|c|c|c|c|}
\hline \multirow[b]{2}{*}{ Suspected risk factor } & \multirow{2}{*}{$\begin{array}{l}\text { Type of } \\
\text { control }\end{array}$} & \multicolumn{2}{|c|}{ Cases } & \multicolumn{2}{|c|}{ Controls } & \multirow{2}{*}{$\begin{array}{l}\text { Relative } \\
\text { risk }\end{array}$} & \multirow{2}{*}{$\begin{array}{c}95 \% \\
\text { Confidence } \\
\text { interval }\end{array}$} \\
\hline & & Total & Positive & Total & Positive & & \\
\hline \multicolumn{8}{|c|}{ Leukaemia } \\
\hline Maternal viral & Area & 35 & 2 & 119 & 7 & $1 \cdot 12$ & 0.22 to 5.67 \\
\hline $\begin{array}{l}\text { infection in } \\
\text { pregnancy }\end{array}$ & Local & 35 & 2 & 103 & 6 & $1 \cdot 23$ & $0 \cdot 22$ to $7 \cdot 04$ \\
\hline Caesarean delivery & Area & 20 & 2 & 116 & 8 & $1 \cdot 38$ & 0.27 to 6.99 \\
\hline & Local & 20 & 2 & 109 & 9 & $1 \cdot 17$ & 0.24 to 5.81 \\
\hline Social class` & Area & 44 & 9 & 293 & 54 & $1 \cdot 14$ & 0.50 to 2.60 \\
\hline (birth certificate) & Local & 44 & 9 & 287 & 75 & 0.61 & 0.25 to 1.47 \\
\hline Social class ${ }^{\star}$ & Area & 20 & 5 & 51 & 16 & $0 \cdot 90$ & 0.24 to 3.34 \\
\hline (questionnaire) & Local & 19 & 5 & 54 & 21 & $0 \cdot 60$ & $0 \cdot 17$ to $2 \cdot 10$ \\
\hline Mother's age & Area & 52 & 32 & 351 & 220 & 0.94 & 0.51 to 1.72 \\
\hline$(\geqslant 25 v<25$ years $)$ & Local & 52 & 32 & 344 & 213 & 0.96 & 0.52 to 1.78 \\
\hline Mother's age & Area & 52 & 4 & 351 & 6 & 4.94 & $1 \cdot 11$ to $21 \cdot 85$ \\
\hline$(\geqslant 40 v<25$ years $)$ & Local & 52 & 4 & 344 & 8 & $3 \cdot 38$ & 0.88 to 13.03 \\
\hline Father's age & Area & 46 & 38 & 287 & 220 & 1.42 & 0.63 to $3 \cdot 18$ \\
\hline$(\geqslant 25 v<25$ years $)$ & Local & 46 & 38 & 276 & 213 & 1.43 & 0.61 to 3.33 \\
\hline Father's age & Area & 46 & 6 & 287 & 26 & 1.87 & 0.59 to 5.91 \\
\hline$(\geqslant 40 v<25$ years $)$ & Local & 46 & 6 & 276 & 24 & $2 \cdot 27$ & 0.66 to 7.76 \\
\hline Birth weight & Area & 18 & 7 & 99 & 42 & 0.88 & 0.32 to 2.42 \\
\hline$(\geqslant 3.5 v<3.5 \mathrm{~kg})$ & Local & 18 & 7 & 94 & 41 & 0.84 & 0.29 to 2.42 \\
\hline \multicolumn{8}{|c|}{ Leukaemia and non-Hodgkin's lymphoma } \\
\hline Maternal viral & Area & 47 & 2 & 156 & 12 & 0.69 & $0 \cdot 15$ to $3 \cdot 24$ \\
\hline $\begin{array}{l}\text { infection in } \\
\text { pregnancy }\end{array}$ & Local & 46 & 2 & 144 & 8 & 0.94 & $0 \cdot 18$ to $4 \cdot 87$ \\
\hline Caesarean & Area & 28 & 2 & 167 & 15 & $0 \cdot 75$ & $0 \cdot 16$ to 3.56 \\
\hline delivery & Local & 28 & 2 & 153 & 11 & 0.95 & 0.20 to 4.50 \\
\hline Social class` & Area & 64 & 14 & 418 & 75 & $1 \cdot 33$ & 0.68 to 2.59 \\
\hline (birth certificate) & Local & 64 & 14 & 408 & 100 & $0 \cdot 70$ & 0.33 to 1.49 \\
\hline Social class ${ }^{\star}$ & Area & 26 & 7 & 70 & 20 & $1 \cdot 11$ & 0.34 to 3.64 \\
\hline (questionnaire) & Local & 25 & 7 & 75 & 30 & 0.61 & 0.21 to 1.79 \\
\hline Mother's age & Area & 74 & 47 & 492 & 311 & 0.99 & 0.60 to 1.65 \\
\hline$(\geqslant 25 v<25$ years $)$ & Local & 74 & 47 & 484 & 305 & 0.99 & 0.59 to 1.66 \\
\hline Mother's age & Area & 74 & 7 & 492 & 10 & $5 \cdot 08$ & 1.66 to 15.53 \\
\hline$(\geqslant 40 v<25$ years $)$ & Local & 74 & 7 & 484 & 12 & $4 \cdot 03$ & 1.41 to 11.52 \\
\hline Father's age & Area & 66 & 52 & 403 & 318 & 0.95 & 0.50 to 1.79 \\
\hline$(\geqslant 25 v<25$ years $)$ & Local & 66 & 52 & 389 & 304 & 1.00 & 0.51 to 1.93 \\
\hline Father's age & Area & 66 & 9 & 403 & 34 & 1.51 & 0.60 to 3.78 \\
\hline$(\geqslant 40 v<25$ years $)$ & Local & 66 & 9 & 389 & 34 & 1.58 & $0 \cdot 60$ to $4 \cdot 16$ \\
\hline Birth weight & Area & 26 & 11 & 149 & 62 & 1.01 & 0.44 to 2.34 \\
\hline$(\geqslant 3.5 v<3.5 \mathrm{~kg})$ & Local & 26 & ii & 137 & 64 & 0.86 & 0.37 to 2.01 \\
\hline
\end{tabular}

* Social class of father at child's birth: I, II, III non-manual $v$ III manual, IV, $\mathrm{V}$. abdominal radiographic examinations according to whether the information was obtained from obstetric records or questionnaire responses. The relative risks ranged from about $1 \cdot 2$ to $1 \cdot 7$, comparable to levels reported in earlier studies. This study was too small for meaningful analysis by number of films or trimester of exposure.

For cases of Hodgkin's disease a report of an abdominal $x$ ray examination was made for none of the six mothers for whom we located obstetric records and by two of the 12 parents who responded on the questionnaire.

VIRAL INFECTIONS AND OTHER SUSPECTED RISK FACTORS

Only one episode of viral infectious illness during pregnancy was recorded in the hospital records examined, so analysis was restricted to data from the questionnaires. Results for any episode of chickenpox, shingles, influenza, measles, or rubella are given in table II, with no strong finding. Also shown are relative risks, again based on small numbers, for delivery by caesarean section based on information from obstetric records.

Findings are given for social class based on occupation at birth as recorded on each of birth certificates and questionnaires, and the similar results reflect the high level of agreement between the data sources. The table shows relative risks around unity for a broad higher social class category in relation to area controls but lower values for local controls. More detailed analysis did not identify any strong trends by social class.

Relative risks around unity were also found for maternal age at birth of 25 or older compared with under 25 years. For mothers of 40 or older, however, when examined in a comparison of all age groups - that is, $<25,25-29,30-34,35-39$, and $\geqslant 40$ years-relative risks were about 4 . The latter finding was much less strong for fathers. Birth weight, from obstetric records, showed no particular relation in either the broad categories listed or smaller groups.

For Hodgkin's disease there were no important relationships with any of the above factors including parental ages.

\section{QUESTIONNAIRE HABIT FACTORS}

Table III shows findings based on the behavioural data obtained by questionnaire. The factors included, particularly those for which there were data on substantial numbers of cases, did not show any important relations with leukaemia and non-Hodgkin's lymphoma. Results for playing on the beach are shown in the table with all cases for whom information was available. Children aged under 5 years at diagnosis were less likely because of their illness to have played in the sand, and excluding these cases and their controls made little difference, with the relative risks against area controls for leukaemia alone and combined with non-Hodgkin's lymphoma becoming 0.83 and 1.04 respectively. The relative risks for play on the fells were particularly low.

Analysis by fish eating habits did not indicate any associated risk. For shellfish eating the relative risks were raised compared with area controls but not compared with local controls; the raised relative risks were, however, based on only two exposed cases (both diagnosed before 1980). Restriction of these analyses to cases born during periods when discharges from Sellafield were highest did not show any important differential relative risks. Finally, there was no evidence of any increased risk in conjunction with families growing their own vegetables or using seaweed as a fertiliser.

There were no important relationships of Hodgkin's disease with these factors. 
TABLE III - Numbers of cases and controls with relative risks for leukaemia and non-Hodgkin's lımphoma in children by family habit factors from parental questionnaire

\begin{tabular}{|c|c|c|c|c|c|c|c|}
\hline \multirow[b]{2}{*}{ Habit factor } & \multirow{2}{*}{$\begin{array}{l}\text { Type of } \\
\text { control }\end{array}$} & \multicolumn{2}{|c|}{ Cases } & \multicolumn{2}{|c|}{ Controls } & \multirow{2}{*}{$\begin{array}{c}\text { Relative } \\
\text { risk }\end{array}$} & \multirow{2}{*}{$\begin{array}{c}95 \% \\
\text { Confidence } \\
\text { interval }\end{array}$} \\
\hline & & Total & Positive & Total & Positive & & \\
\hline \multicolumn{8}{|c|}{ Leukaemia } \\
\hline Play on beach & Area & 28 & 13 & 94 & 47 & 0.89 & 0.37 to $2 \cdot 17$ \\
\hline $\begin{array}{l}\text { more } r \text { less often } \\
\text { than monthly }\end{array}$ & Local & 28 & 13 & 92 & 57 & 0.62 & 0.24 to 1.59 \\
\hline Play on fells & Area & 27 & 3 & 77 & 23 & $0 \cdot 29$ & 0.06 to 1.39 \\
\hline $\begin{array}{l}\text { more a less often } \\
\text { than monthly) }\end{array}$ & Local & 24 & 3 & 71 & 18 & 0.53 & $0 \cdot 14$ to $2 \cdot 07$ \\
\hline Eating fish & Area & 29 & 16 & 97 & 49 & $1 \cdot 26$ & 0.50 to 3.21 \\
\hline $\begin{array}{l}\text { more } a \text { less often } \\
\text { than weekly) }\end{array}$ & Local & 28 & 16 & 93 & 49 & $1 \cdot 16$ & $0 \cdot 45$ to $3 \cdot 00$ \\
\hline Eating shellfish & Area & 15 & 2 & 36 & 1 & $7 \cdot 03$ & 0.61 to 80.43 \\
\hline $\begin{array}{l}\text { more } v \text { less often } \\
\text { than weekly) }\end{array}$ & Local & 15 & 2 & 29 & 3 & $1 \cdot 11$ & 0.15 to 7.91 \\
\hline Grow own & Area & 35 & 15 & 123 & 54 & 0.98 & $0 \cdot 45$ to $2 \cdot 13$ \\
\hline vegetables & Local & 35 & 15 & 112 & 45 & 1.07 & 0.46 to 2.48 \\
\hline Seaweed as & Area & 11 & 1 & 25 & 1 & 1.73 & $0 \cdot 10$ to $30 \cdot 76$ \\
\hline fertiliser & Local & 13 & 1 & 25 & 1 & $2 \cdot 00$ & 0.13 to 31.98 \\
\hline \multicolumn{8}{|c|}{ Leukaemia and non-Hodgkin's lymphoma } \\
\hline Play on beach & Area & 40 & 18 & 131 & 61 & 0.95 & 0.45 to $2 \cdot 00$ \\
\hline $\begin{array}{l}\text { more } i \text { less often } \\
\text { than monthly }\end{array}$ & Local & 39 & 18 & 131 & 78 & 0.66 & 0.31 to 1.40 \\
\hline Play on fells & Area & 36 & 4 & 103 & 28 & $0 \cdot 33$ & 0.09 to 1.21 \\
\hline $\begin{array}{l}\text { more } 2 \text { less often } \\
\text { than monthly }\end{array}$ & Local & 32 & 4 & 98 & 31 & 0.36 & 0.11 to 1.17 \\
\hline Eating fish & Area & 39 & 20 & 126 & 62 & 1.03 & 0.45 to 2.37 \\
\hline $\begin{array}{l}\text { more } v \text { less often } \\
\text { than weekly }\end{array}$ & Local & 36 & 19 & 127 & 67 & 0.86 & 0.38 to 1.98 \\
\hline Eating shellfish & Area & 19 & 2 & 44 & 2 & 2.99 & $0 \cdot 40$ to $22 \cdot 11$ \\
\hline $\begin{array}{l}\text { more } a \text { less often } \\
\text { than weekly }\end{array}$ & Local & 18 & 2 & 39 & 5 & 0.82 & 0.14 to 5.01 \\
\hline Grow own & Area & 47 & 20 & 161 & 71 & 0.99 & 0.52 to 1.93 \\
\hline vegetables & Local & 46 & 20 & 154 & 72 & $0 \cdot 87$ & 0.42 to 1.81 \\
\hline Seaweed as & Area & 15 & 1 & 30 & 1 & 1.73 & $0 \cdot 10$ to $30 \cdot 76$ \\
\hline fertiliser & Local & 17 & 1 & 36 & $i$ & $2 \cdot 00$ & 0.13 to 31.98 \\
\hline
\end{tabular}

TABLE IV - Numbers of cases and controls with relative risks for leukaemia and non-Hodgkin's lymphoma in children by distance from Sellafield of residence at birth for area controls

\begin{tabular}{|c|c|c|c|c|c|c|c|c|}
\hline \multirow[b]{2}{*}{ Distance $(\mathrm{km})$} & \multicolumn{4}{|c|}{ Leukaemia } & \multicolumn{4}{|c|}{ Leukaemia and non-Hodgkin's lymphoma } \\
\hline & $\begin{array}{c}\text { Cases } \\
(\mathrm{n}=51)\end{array}$ & $\begin{array}{c}\text { Area } \\
\text { controls } \\
\mathrm{n}=350\end{array}$ & $\begin{array}{c}\text { Relative } \\
\text { risk }\end{array}$ & $\begin{array}{c}95 \% \\
\text { Confidence } \\
\text { interval }\end{array}$ & $\begin{array}{c}\text { Cases } \\
(\mathrm{n}=73\end{array}$ & $\begin{array}{c}\text { Area } \\
\text { controls } \\
(\mathrm{n}=491)\end{array}$ & $\begin{array}{c}\text { Relative } \\
\text { risk }\end{array}$ & $\begin{array}{c}95 \% \\
\text { Confidence } \\
\text { interval }\end{array}$ \\
\hline$\leqslant 4$ & 5 & 14 & 1 & & 8 & 16 & 1 & \\
\hline $5-9$ & 5 & 31 & $0 \cdot 35$ & 0.08 to 1.62 & 6 & 43 & $0 \cdot 21$ & 0.06 to 0.78 \\
\hline $10-14$ & 14 & 117 & $0 \cdot 21$ & 0.05 to 0.92 & 22 & 160 & $0 \cdot 17$ & 0.05 to 0.56 \\
\hline $15-19$ & 5 & 35 & 0.22 & 0.04 to 1.22 & 8 & 50 & $0 \cdot 16$ & 0.04 to 0.67 \\
\hline $20-24$ & 9 & 52 & 0.22 & 0.03 to 1.59 & 11 & 84 & 0.07 & 0.01 to 0.38 \\
\hline $25-29$ & 8 & 66 & $0 \cdot 14$ & 0.02 to 0.91 & 12 & 100 & $0 \cdot 06$ & 0.01 to 0.31 \\
\hline$\geqslant 30$ & 5 & 35 & $0 \cdot 17$ & 0.02 to 1.88 & 6 & 38 & $0 \cdot 11$ & 0.02 to 0.80 \\
\hline
\end{tabular}

GEOGRAPHY OF CASES AND CONTROLS RELATIVE TO SELLAFIELD

Distances of addresses of cases and controls from Sellafield were calculated by taking the grid reference of the plant to be NY 027039 as used by the National Radiological Protection Board in its analysis of atmospheric discharges (J Stather, personal communication). The results given here are for area controls using addresses at birth. Table IV shows findings in circles of increasing $5 \mathrm{~km}$ radiuses moving away from Sellafield, and risks are given relative to the inner circle (which completely contains Seascale and some other smaller villages). All five cases of leukaemia and two of the three cases of non-Hodgkin's lymphoma in the inner circle occurred in children born to parents resident in Seascale. There was a large fall in relative risk in moving to outside the inner circle to levels of about one third and smaller, with some suggestion also of a decreasing risk with further distance. For leukaemia and non-Hodgkin's lymphoma combined the relative risks away from the inner circle were lower than for leukaemia alone. The relative risk of leukaemia for all children born outside the inner circle was $0.26(95 \%$ confidence interval 0.07 to 1.01 ) and for leukaemia and non-Hodgkin's lymphoma together it was $0 \cdot 17(95 \%$ confidence interval 0.05 to 0.53 ). These latter results also applied when analysis was limited to cases born in the birth registration district containing Sellafield rather than all West Cumbria. None of the 23 cases of
Hodgkin's disease in the study had an address at birth within the $5 \mathrm{~km}$ radius inner circle. Of the 95 total cases with complete information $79(83 \%)$ remained in the same $5 \mathrm{~km}$ sector from birth to diagnosis.

\section{FATHER'S OCCUPATION AND EMPLOYMENT AT SELLAFIELD}

Three separate sources of parental occupational information were used: birth certificates, questionnaires, and the computer file of past and present workers at Sellafield. Maternal occupation is generally recorded on a birth certificate only in the absence of paternal occupation, questionnaire data were available for only about half the study members, and relatively few women have worked at Sellafield, so results given here are restricted to father's employment .

Table $\mathrm{V}$ shows the relative risks for leukaemia and non-Hodgkin's lymphoma associated with various paternal employment categories. These data were taken from birth certificates rather than questionnaires because of the greater completeness of information for example, data for the 74 fathers of children with leukaemia and non-Hodgkin's lymphoma were available from $64(86 \%)$ birth certificates but only 32 $(43 \%)$ questionnaires. Results are given for the main industrial groups in West Cumbria which employed more than $5 \%$ of control fathers. Raised relative risks were associated with fathers working at Sellafield and in iron and steel, farming, and chemicals, with children of coal miners having low relative risks but based on small numbers. Similar results were found using the questionnaire data and when examining employment on the questionnaire at conception rather than birth, although then relative risks were somewhat higher in relation to Sellafield and farming than those shown in table $\mathrm{V}$.

For Hodgkin's disease the relative risks associated with fathers working at Sellafield according to data from birth certificates were low - for example, for local controls the relative risk was 0.71 (95\% confidence interval 0.08 to 6.03 ). This result was based on only one positive case, since, although we had records that four fathers altogether were Sellafield workers, for three this employment occurred after the birth of their children.

\section{RADIATION DOSIMETRY AT SELLAFIELD}

Table VI shows relative risks for leukaemia and non-Hodgkin's lymphoma in children associated with

TABLE $\mathrm{v}-$ Numbers of cases and controls with relative risks for leukaemia and non-Hodgkin's lymphoma in children by paternal occupation and industry recorded on birth certificates

\begin{tabular}{|c|c|c|c|c|c|}
\hline $\begin{array}{l}\text { Father's occupation/ } \\
\text { industry }\end{array}$ & $\begin{array}{l}\text { Type of } \\
\text { control }\end{array}$ & Cases & \multicolumn{2}{|c|}{ Controls risk } & $\begin{array}{c}95 \% \\
\text { e Confidence } \\
\text { interval }\end{array}$ \\
\hline \multicolumn{6}{|c|}{ Leukaemia } \\
\hline \multirow[t]{2}{*}{ Total } & Area & 46 & 286 & & \\
\hline & Local & 46 & 277 & & \\
\hline \multirow[t]{2}{*}{ Sellafield } & Area & 9 & 29 & $2 \cdot 82$ & 1.07 to 7.40 \\
\hline & Local & 9 & 41 & $2 \cdot 03$ & 0.69 to 5.93 \\
\hline \multirow[t]{2}{*}{ Coal mining } & Area & 2 & 33 & $0 \cdot 37$ & 0.09 to 1.61 \\
\hline & Local & 2 & 31 & $0 \cdot 35$ & 0.08 to 1.60 \\
\hline \multirow[t]{2}{*}{ Iron and steel } & Area & 5 & 18 & 1.84 & 0.60 to 5.60 \\
\hline & Local & 5 & 16 & $2 \cdot 36$ & 0.71 to 7.78 \\
\hline \multirow[t]{2}{*}{ Farming } & Area & 5 & 19 & 1.98 & 0.66 to 5.96 \\
\hline & Local & 5 & 11 & $2 \cdot 63$ & 0.77 to. 8.95 \\
\hline \multirow[t]{2}{*}{ Chemicals } & Area & 5 & 25 & $1 \cdot 39$ & 0.49 to 3.97 \\
\hline & Local & 5 & 23 & 1.58 & 0.52 to 4.84 \\
\hline \multicolumn{6}{|c|}{ Leukaemia and non-Hodgkin's lymphoma } \\
\hline \multirow[t]{2}{*}{ Total } & Area & 64 & 393 & & \\
\hline & Local & 64 & 383 & & \\
\hline \multirow[t]{2}{*}{ Sellafield } & Area & 10 & 38 & $2 \cdot 02$ & $0.87 \mathrm{to} 4.67$ \\
\hline & Local & 10 & 54 & $1 \cdot 32$ & 0.51 to 3.43 \\
\hline \multirow[t]{2}{*}{ Coal mining } & Area & 5 & 53 & 0.51 & 0.19 to 1.39 \\
\hline & Local & 5 & 53 & $0 \cdot 46$ & 0.16 to 1.30 \\
\hline \multirow[t]{2}{*}{ Iron and steel } & Area & 9 & 31 & $2 \cdot 06$ & 0.88 to 4.82 \\
\hline & Local & 9 & 25 & $3 \cdot 20$ & 1.23 to 8.28 \\
\hline \multirow[t]{2}{*}{ Farming } & Area & 6 & 27 & 1.54 & 0.57 to 4.11 \\
\hline & Local & 6 & 16 & $2 \cdot 15$ & 0.71 to 6.51 \\
\hline \multirow[t]{2}{*}{ Chemicals } & Area & 7 & 27 & 1.90 & 0.75 to 4.78 \\
\hline & Local & 7 & 25 & $2 \cdot 15$ & 0.80 to 5.77 \\
\hline
\end{tabular}


TABLE VI-Numbers of cases and controls with relative risks for leukaemia and non-Hodgkin's lymphoma in children by timing of paternal employment and external ionising radiation dosimetry at Sellafield

\begin{tabular}{|c|c|c|c|c|c|}
\hline $\begin{array}{l}\text { Father's employment/ } \\
\text { radiation group }\end{array}$ & $\begin{array}{l}\text { Type of } \\
\text { control }\end{array}$ & Cases & Controls & $\begin{array}{l}\text { Relative } \\
\text { risk }\end{array}$ & $\begin{array}{c}95 \% \\
\text { e Confidence } \\
\text { interval }\end{array}$ \\
\hline \multicolumn{6}{|c|}{ Leukaemia } \\
\hline Total & $\begin{array}{l}\text { Area } \\
\text { Local }\end{array}$ & $\begin{array}{l}46 \\
46\end{array}$ & $\begin{array}{l}288 \\
276\end{array}$ & & \\
\hline \multicolumn{6}{|l|}{ Employed: } \\
\hline Before conception & Area & 9 & 36 & 1.97 & 0.82 to 4.78 \\
\hline \multirow[t]{2}{*}{ At conception } & $\begin{array}{l}\text { Local } \\
\text { Area }\end{array}$ & $\begin{array}{l}9 \\
8\end{array}$ & $\begin{array}{l}45 \\
25\end{array}$ & $\begin{array}{l}1 \cdot 39 \\
2 \cdot 79\end{array}$ & $\begin{array}{l}0.53 \text { to } 3.65 \\
1.04 \text { to } 7.52\end{array}$ \\
\hline & Local & 8 & 32 & $2 \cdot 07$ & 0.69 to 6.14 \\
\hline \multirow[t]{2}{*}{ At birth } & Area & 8 & 27 & $2 \cdot 51$ & 0.95 to 6.67 \\
\hline & Local & 8 & 33 & 1.92 & 0.66 to 5.56 \\
\hline \multirow[t]{2}{*}{ Before diagnosis } & Area & 9 & 53 & $1 \cdot 17$ & 0.49 to 2.76 \\
\hline & Local & 9 & 58 & 0.89 & 0.36 to $2 \cdot 18$ \\
\hline \multirow[t]{2}{*}{ Ever } & Area & 12 & 65 & $1 \cdot 35$ & 0.61 to 2.96 \\
\hline & Local & 12 & 65 & $1 \cdot 22$ & 0.54 to 2.74 \\
\hline \multicolumn{6}{|l|}{ Dose record: } \\
\hline \multirow[t]{2}{*}{ Before conception } & Area & 8 & 35 & $1 \cdot 71$ & 0.68 to $4 \cdot 26$ \\
\hline & Local & 8 & 40 & $1 \cdot 40$ & 3.94 \\
\hline \multirow[t]{2}{*}{ At conception } & Area & 8 & 24 & 3.07 & 1.09 to 8.65 \\
\hline & Local & 8 & 30 & $2 \cdot 43$ & 0.80 to 7.41 \\
\hline \multirow[t]{2}{*}{ Before diagnosis } & Area & 8 & 48 & $1 \cdot 11$ & 0.45 to 2.72 \\
\hline & Local & 8 & 54 & $0 \cdot 81$ & $0 \cdot 31$ to $2 \cdot 10$ \\
\hline \multicolumn{6}{|c|}{ Total dose before conception: } \\
\hline $1-49 \mathrm{mSv}$ & Area & 3 & 19 & $1 \cdot 12$ & 0.31 to 4.05 \\
\hline & Local & 3 & 26 & $0 \cdot 77$ & 0.20 to 3.00 \\
\hline $50-99 \mathrm{mSv}$ & Area & 1 & 11 & 0.69 & 0.08 to 5.73 \\
\hline & Local & 1 & 11 & 0.78 & 0.08 to $7 \cdot 73$ \\
\hline$\geqslant 100 \mathrm{mSv}$ & Are & 4 & 5 & $6 \cdot 24$ & 1.51 to 25.76 \\
\hline & Local & 4 & 3 & $8 \cdot 38$ & 1.35 to 51.99 \\
\hline Dose during 6 months & ore conce & ption: & & & \\
\hline $1-4 \mathrm{mSv}$ & Area & 3 & 18 & $1 \cdot 30$ & 0.32 to 5.34 \\
\hline & Local & 3 & 24 & $1 \cdot 10$ & 0.25 to 4.91 \\
\hline $5-9 \mathrm{mSv}$ & Ar & 1 & 3 & $3 \cdot 54$ & $0 \cdot 32$ to $38 \cdot 88$ \\
\hline & Local & 1 & 3 & 3.04 & 0.28 to 32.61 \\
\hline$\geqslant 10 \mathrm{mSv}$ & Are & 4 & 5 & $7 \cdot 17$ & 1.69 to 30.44 \\
\hline & Local & 4 & 3 & $8 \cdot 21$ & 1.62 to 41.73 \\
\hline Leukc & ia and no & $n$-Hodgk & kin's lymph & homa & \\
\hline Total & Area & 66 & 404 & & \\
\hline & Local & 66 & 389 & & \\
\hline Employed: & & & & & \\
\hline Before conception & Area & 11 & 47 & $1 \cdot 77$ & 0.82 to 3.85 \\
\hline & Local & 11 & & 1.08 & 0.47 to 2.52 \\
\hline At conception & Area & 10 & 34 & $2 \cdot 44$ & 1.04 to 5.71 \\
\hline & Local & 10 & & 1.48 & 0.59 to 3.75 \\
\hline At birth & Area & 10 & 37 & $2 \cdot 14$ & 0.93 to 4.92 \\
\hline & Local & 10 & 50 & $1 \cdot 26$ & 0.48 to 3.28 \\
\hline Before diagnosis & Area & 11 & 72 & 0.97 & 0.46 to 2.03 \\
\hline & & 11 & 83 & 0.64 & \\
\hline Ever & Area & 14 & 88 & 1.01 & 0.51 to 2.02 \\
\hline & & 14 & & & 1.69 \\
\hline Dose record: & Area & 10 & 45 & 1.63 & 03.64 \\
\hline Before conception & & 10 & 58 & & 0.40 to 2.51 \\
\hline & Area & 10 & 32 & $2 \cdot 71$ & $1 \cdot 12$ to 6.60 \\
\hline At conception & Local & 10 & 45 & 1.58 & $0 \cdot 60$ to $4 \cdot 18$ \\
\hline & & 10 & 66 & 0.95 & 0.44 to 2.05 \\
\hline Before diagnosis & Local & 10 & 78 & $0 \cdot 60$ & 0.25 to 1.41 \\
\hline Total dose before co & ion: & & & & \\
\hline $1-49 \mathrm{mSv}$ & Area & 4 & 27 & 1.06 & 0.35 to 3.21 \\
\hline & & 4 & & & \\
\hline $50-99 \mathrm{mSv}$ & Are & 2 & 13 & 1 . & 0.24 to 5.46 \\
\hline & & 2 & 14 & & \\
\hline$\geqslant 100 \mathrm{mSv}$ & Area & 4 & 5 & $6 \cdot 42$ & 1.57 to 26.32 \\
\hline & Local & 4 & 3 & $8 \cdot 30$ & 1.36 to 50.56 \\
\hline Dose during 6 montl & ore conce & tion: & & & \\
\hline $1-4 \mathrm{mSv}$ & Area & 5 & 22 & $1 \cdot 80$ & \\
\hline & & 5 & 33 & 0.97 & $0 \cdot 28$ to $3 \cdot 41$ \\
\hline $5-9 \mathrm{mSv}$ & Area & 1 & 4 & $2 \cdot 41$ & 0.25 to 23.43 \\
\hline & Local & 1 & 7 & $1 \cdot 12$ & 0.13 to 9.93 \\
\hline$\geqslant 10 \mathrm{mSv}$ & Area & 4 & 8 & $4 \cdot 33$ & $1 \cdot 16$ to $16 \cdot 12$ \\
\hline & Local & 4 & 5 & 5.01 & 1.13 to 22.24 \\
\hline
\end{tabular}

their fathers' employment and exposure to ionising radiation obtained through linkage with the Sellafield workforce file. As well as analysing the total radiation dose recorded before conception (taken as nine months before birth) we looked at that during the immediately preceding six months, since it has been suggested that this is the most sensitive period for the induction of transmissible genetic damage.$^{6}$ The six monthly doses were estimated proportionally from the recorded annual doses of the father and the date of birth of his child.

For paternal employment at the plant relative risks were higher for leukaemia alone than for leukaemia and non-Hodgkin's lymphoma combined and were higher for employment at conception than at any other time. Relative risks for leukaemia and non-Hodgkin's lymphoma were higher for fathers with a radiation dose record at conception than for those with a radiation dose record at any time before conception or diagnosis. The highest relative risks - of the order of sixfoldwere for fathers with total radiation doses of $100 \mathrm{mSv}$ or greater before the date of their child's conception or doses of $10 \mathrm{mSv}$ or greater during the six months before conception. Figures for all the control fathers in this study indicated that about $9 \%$ of the workforce had had accumulated preconceptual doses over $100 \mathrm{mSv}$ and about $13 \%$ had had doses over $10 \mathrm{mSv}$ during the six months before conception.

The results shown in the table relate to all fathers in the study for whom we could make a definite positive or negative linkage to the Sellafield file. The same analysis limited to fathers positively linked to the Sellafield file showed similar relations to ionising radiation dose but with larger relative risks in the highest categories. For example, there was a relative risk of $17 \cdot 2$ for leukaemia compared with area controls in children of fathers with total radiation doses before conception of $100 \mathrm{mSv}$ or more with a $95 \%$ confidence interval of $1 \cdot 1$ to 278 , the wide interval reflecting that the analysis was based on a total of 11 case-control sets rather than 46 as in the table.

For cases of Hodgkin's disease none of the four fathers employed at Sellafield had a record of occupational radiation exposure before their child's conception.

\section{SEASCALE}

Earlier studies have concentrated on the geographical excess of childhood leukaemia in the neighbourhood of the Sellafield plant. This excess was found in Seascale particularly and was based on around five cases compared with fewer than one expected, depending on which age group and calendar period were reported. A pertinent question is to what degree this excess may be explained statistically by the demonstrated relationship with paternal radiation dose during employment.

Three of the five Seascale cases in this study were among the four cases of leukaemia with fathers in the highest total radiation dose group (table VI), with doses of $102 \mathrm{mSv}$ (over about 7 years' employment), $162 \mathrm{mSv}$ (about 6 years), and $188 \mathrm{mSv}$ (about 7 years). The one case in the intermediate group was also from Seascale, with a paternal total dose of $97 \mathrm{mSv}$ (over about 13 years). The fifth Seascale leukaemia case was not, however, linked with the Sellafield computer file owing to our being unable to trace a date of birth for his father, although we know that the father worked at Sellafield from the child's birth certificate and the mother's questionnaire. Thus, we know that three of the five Seascale cases had fathers whose accumulated preconceptual radiation dose was in the group with an estimated sixfold to eightfold relative risk of leukaemia and the father of the fourth was in the group just below the cut off value used. These five Seascale leukaemia cases were precisely those in the inner circle of table IV, where the risk was highest.

If the exposure of the father to ionising radiation was the cause of leukaemia in the children then the reported geographical excess could effectively be explained on this basis. If, alternatively, the fact of living in Seascale itself were responsible for the excess then it would not be expected that three of the four fathers linked to the Sellafield workforce file would have a total radiation dose before conception in the highest category, whereas 16 out of 20 fathers of the local controls for these four cases (also born to mothers resident in Seascale) had a radiation record with only one in the highest category (the other four had not been employed at Sellafield). Moreover, in no father of the 20 local controls was their total preconception dose as high as in the father of their related case. For fathers of the area 
controls the corresponding figures were 9 out of 27 with a radiation record but none in the highest category ( 17 of the other 18 had not been employed at Sellafield), and all the total preconception doses of the fathers of the 27 area controls were lower than those of the father of their related case. These comparisons are shown in table VII and graphically in the figure, where case 1 was in the intermediate dose category of table VI and cases 2, 3, and 4 in the highest category. Similar results

TABLE VII - Numbers of Seascale leukaemia cases and their controls by paternal employment and total external ionising radiation dose at Sellafield before their child's conception *

\begin{tabular}{lccc}
\hline \multirow{2}{*}{$\begin{array}{l}\text { Paternal employment/ } \\
\text { preconceptual radiation dose }\end{array}$} & & \multicolumn{2}{c}{ Controls } \\
\cline { 2 - 4 } at Sellafield & Cases & Local & Area \\
\hline Not employed & 0 & 4 & 17 \\
No dose record & 0 & 0 & 1 \\
$1-49 \mathrm{mSv}$ & 0 & 8 & 6 \\
$50-99 \mathrm{mSv}$ & 1 & 7 & 3 \\
$\geqslant 100 \mathrm{mSv}$ & 3 & 1 & 0 \\
\hline Total & 4 & 20 & 27
\end{tabular}

*One Seascale case (and associated controls) is omitted from this table owing to lack of information on the father (see text). The 20 local controls, as the four cases, were all born to mothers resident in Seascale but only four of the 27 area controls

were found for radiation dose during the six months before conception, except that two of the 18 fathers of the total of 43 controls with a radiation record during this period had higher doses than the father of their associated case. Two mothers of the five leukaemia cases had been employed at Sellafield; neither worked there at the time of conception of their child, but one had experienced previous exposure to radiation (of $26 \mathrm{mSv}$ ) at the plant.

None of the 23 cases of Hodgkin's disease had an address at birth in Seascale.

\section{Discussion}

The main finding of this study is that the recorded external dose of whole body ionising radiation to fathers during their employment at Sellafield is associated with the development of leukaemia among their children. Since radiation badge recording will reflect gonadal dose we interpret this finding to suggest

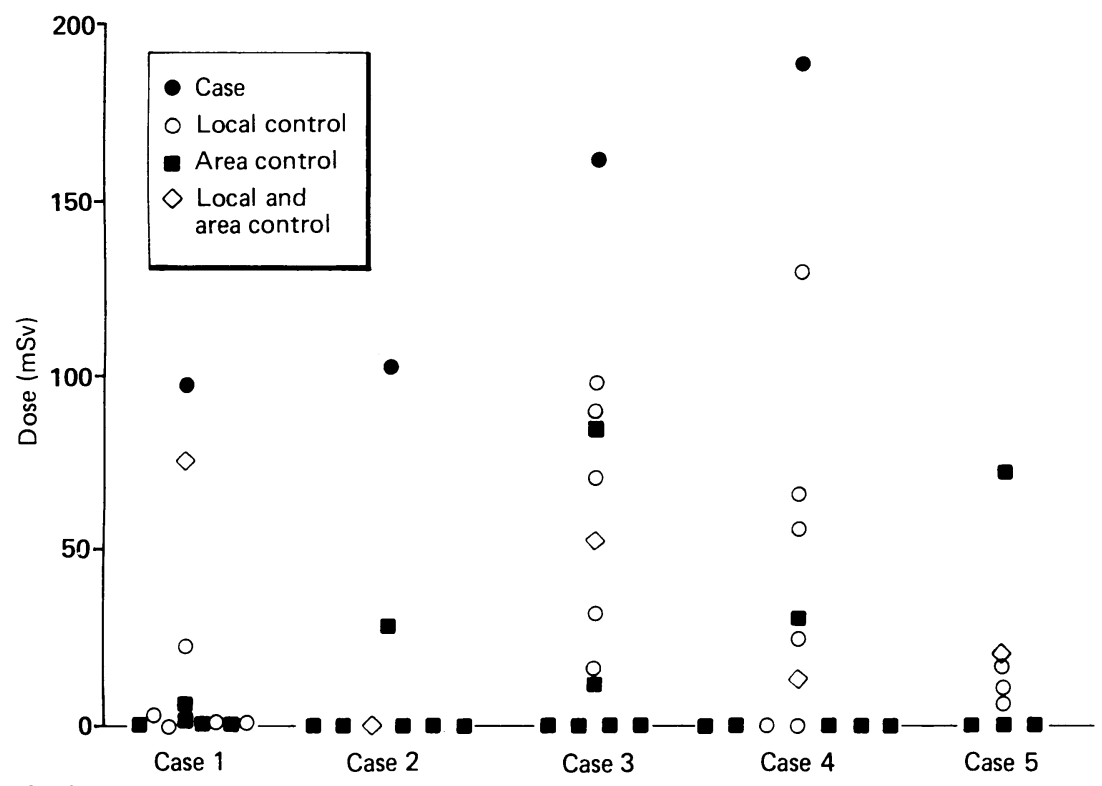

Total external ionising radiation dose during employment at Sellafield before the child's conception in fathers of Seascale leukaemia cases and in fathers of their controls (case 5 not linked to Sellafield workforce file). The different numbers of controls for each case are due to loss from the study of original controls who had moved from Seascale before their case's diagnosis and varying success in identifying fathers and obtaining information to attempt their linkage to the Sellafield file (see accompanying paper'). The local and local and area controls were born to mothers resident in Seascale at the time (as were the five cases); the area controls were born outside Seascale but resident in the same birth registration district an effect of the radiation exposure on germ cells producing a mutation in sperm that may be leukaemogenic in subsequent offspring. Other explanations may be possible, such as exposure to internally incorporated radionuclides or other concomitant exposures in the workplace: it has not been possible to examine the first of these so far, and the second seems unlikely (see below). Additionally, contamination of the home with radioactive or other material through occupational exposure may be relevant, although there is no evidence to support this.

The results suggest highest risks in those with the highest accumulated ionising radiation doses before conception, either over their total duration of exposure or during the preceding six months. For both periods of exposure the same four cases of leukaemia were in the highest groups, three of them in children born in Seascale, and none were lymphomas. We have not yet examined any other duration of exposure period. Comparison of the relative size of various calculated risks associated with fathers' being employed or having a radiation record at Sellafield either at any time or before the diagnosis of their children's illness supports the relevance of preconceptual exposure.

Other factors that we examined indicated smaller relations with leukaemia. Some of those were expected, such as antenatal exposure to $x$ rays, but the high relative risk in mothers aged over 40 was at least twice that previously reported. 'This was not due to an excess of Down's syndrome as none of the cases in our study born to mothers in this age group had trisomy 21 . The question arises whether any of these other factors explain the relation with paternal radiation dose. The one well established cause of childhood leukaemia, exposure in utero to $x$ rays, is considered to have a relative risk of around 1.5 and be responsible alone for some $5 \%$ of cases. This level of increase is not sufficient to explain the observed relative risks for the highest occupational radiation doses. Moreover, each mother of the four cases in the highest exposure category reported on her questionnaire that she had not had an abdominal $x$ ray examination during pregnancy, although we could trace the hospital record of only one mother to verify this information. The high risk found in mothers aged over 40 was also not an explanation since only one of the four cases in the highest radiation dose group was born to a mother of this age, as was one of three in the lowest group. Neither of these two cases born to mothers aged 40 or over with paternal radiation exposure at Sellafield was born in Seascale.

Of the four cases of leukaemia in the highest radiation dose group three were acute lymphatic leukaemia. The father of the non-Seascale case in this group had a total preconceptual dose of $370 \mathrm{mSv}$ (over about 10 years). On their children's birth certificates two of the fathers were described as process workers, one as an analytical chemist, and the other as a fitter's mate. Although we have not yet examined jobs in detail, these various occupations do not suggest common non-radiation exposures that might be relevant to these findings. We are limited in the identification of individual cases that we can give both from our own ethical considerations and also from our undertakings to the British Medical Association ethical committee and British Nuclear Fuels.

The results for non-Hodgkin's lymphoma, for which the number of cases was much smaller, were less suggestive than for leukaemia. However, one of the two Seascale cases in this study had a father with a total preconceptual radiation dose of $97 \mathrm{mSv}$ (during about 15 years' employment), higher than all 11 related control fathers, of whom six had a radiation record before their child's conception. The father of the other case was not employed at Sellafield. There were no cases of Hodgkin's disease with paternal ionising 
radiation dose records at Sellafield before their conception nor among Seascale children; this lack of association with radiation exposure is as could be expected (see accompanying paper) and strengthens the findings in this paper.

One of the weaknesses of this study might be considered to be the relatively low quality information on potential confounding factors such as antenatal exposure to $x$ rays and infectious illnesses in the mother during pregnancy. Nevertheless, the strength of the observed finding, together with the mothers of the relevant cases not reporting having had an abdominal $x$ ray examination, would suggest that the imperfections in measuring confounders of lower and uncertain risk are not detrimental. Additionally the potential for low quality data on children playing on the beach and families' seafood eating habits, for example, is acknowledged, but this would be a more serious criticism if there had been a trend for positive answers by parents of cases. We recognise also the possibility of bias from the absence of information on some factors for a number of cases and controls, but this is due to the unavailability of old records and our failure to trace parents as well as to parents' failures to respond to the questionnaire. Also this absence of data did not greatly affect what seems to be the important risk variable.

These findings support the hypothesis, incorporated as part of this study, that exposure of fathers to ionising radiation before conception is related to the development of leukaemia in their offspring. The observed finding (the first of its kind with human data), however, is stronger than could have been expected from past knowledge, although relevant studies have largely not been undertaken. In a study of the offspring of 7387 men irradiated to an estimated mean dose of $492 \mathrm{mSv}$ as a result of exposure to atomic bombs in Japan there was no excess of leukaemia ( 5 cases observed, $5 \cdot 2$ expected). ${ }^{8}$ Nevertheless, the radiation doses in Hiroshima and Nagasaki were instantaneous compared with accumulated over years in the Sellafield workers; the different dose rates may be important. Studies of high doses (360-5040 mSv) in mice have, none the less, indicated that paternal (as well as maternal) exposure to $x$ rays induces heritable tumours in their first and second generation progeny, the tumours mainly being in the lung (papillary adenomas) but including lymphocytic leukaemia as well as leading to an increase in anomalies. ${ }^{9}$ It was suggested that this effect might operate through germ line mutations, and the finding lends biological plausibility to the pathway suggested here.

Further data relevant to the results shown here are expected from two other British case-control studies currently in progress. These are in areas around other nuclear installations where excesses of childhood leukaemia in particular, but also of other childhood cancers in one instance, have been reported -Dounreay in Caithness and Aldermaston and Burghfield in Berkshire. ${ }^{1011}$ In the latter report the raised incidence in the neighbourhood was much less than around Sellafield or Dounreay (as it has also been much less around other nuclear plants ${ }^{1}$ ), but this would be expected if the results reported here are applicable since there is no dominant settlement of workers equivalent to Seascale or Thurso. The occupational radiation doses, however, have been somewhat less at these two establishments than at Sellafield. Consideration is currently being given to setting up cohort studies to examine the incidence of cancer among the offspring of nuclear plant workers, as well as other radiation workers, and these are also relevant to provide support or otherwise for the findings shown in this paper..$^{10} 11$

The results here are of interest in relation to those in the cohort studies of Seascale children. ${ }^{1213}$ These showed increased rates of leukaemia and total cancer among children born in Seascale 6 observed cases compared with 0.6 expected and 12 compared with 2.8 respectively) but not among children moving in after birth and attending the local schools ( 0 compared with 0.6 and 4 compared with 4.0 respectively). If there is a causal role for radiation operating through paternal occupational exposure these very different findings among children born in Seascale and those attending school there are as would be expected, apart possibly from the fact that some at least of the Seascale immigrants came from other nuclear establishments. It seems important now not only to extend the cohort studies in time forward from 1983 and backwards before 1950 , which is currently being done, but also to carry out for all parents of children born in Seascale a similar linkage exercise as in this study with the Sellafield workforce file and radiation dose records. Additionally, we are planning to examine recent cases diagnosed in the Seascale area in the same manner as in this study. Furthermore, data on internally incorporated radionuclides will be analysed when these become available. Possibly men with high external doses also have high internal exposure. Certainly some degree of correlation between cumulative radiation dose and monitoring for possible internal contamination by specific radionuclides, including plutonium and tritium, was found among workers at United Kingdom Atomic Energy Authority establishments and the Atomic Weapons Establishment. ${ }^{1+15}$

One of the considerations made at the time of the Black inquiry was that the levels of radioactive discharges from Sellafield to atmosphere and sea were too low to account for the number of excess cases of leukaemia being observed in the Seascale area. ${ }^{2}$ This was based on the relatively small additional contribution from Sellafield to total radiation exposure from natural background, medical, and other sources. This conclusion would be supported by the results in this study for playing on the beach and eating seafood. The findings here in relation to occupational radiation exposure of the father suggest a totally different pathway and do not conflict with that reasoning. These results also make other alternative hypotheses that have been proposed unlikely to be the explanations-for example, that epidemics of common infections produce a leukaemic response by mixing of populations ${ }^{16}$ and that areas chosen as nuclear sites, existing or potential, share unrecognised risk factors.

The range of total preconceptual external radiation doses of fathers in this study was from 0 to $383 \mathrm{mSv}$, the worker with the highest dose being employed over seven years. The range of estimated radiation doses during the six months before conception was 0 to $31 \mathrm{mSv}$. An annual dose limit of $50 \mathrm{mSv}$ for radiation workers was recommended in 1965 by the International Commission on Radiological Protection, ${ }^{18}$ and this figure still operates in the United Kingdom, although in 1987 the National Radiological Protection Board recommended a reduction to $15 \mathrm{mSv}$ per year. During 1987 in the United Kingdom some 1100 workers received annual doses above $15 \mathrm{mSv}$ from artificial sources; most of these worked in nuclear fuel processing, with fewer than 10 being, for example, health professionals. ${ }^{20}$

If the associations reported in this paper are causal they need to be explored further to help determine which period of exposure may be most relevant. Although the two measures we have examined this far are highly correlated and show similar relations, there is a more convincing trend of increasing relative risks of leukaemia for paternal radiation dose during the six months preceding conception than for total exposure (table VI). The findings here contrast with those in the mortality follow up of Sellafield radiation workers 
themselves, among whom there were no excess deaths from leukaemia and only a limited suggestion of an association of death from leukaemia with dose of ionising radiation when considering a lag period of 15 years. ${ }^{21}$ However, if these results have causal significance then they are of much importance to radiological protection of potential parents and their children.

We thank the registration division of the Office of Population Censuses and Surveys, the West Cumbria Health Authority, the Cumbrian Family Practitioner Committee, and other sources mentioned in the text for their cooperation in identifying records on subjects included in the study; the National Health Service central register for providing follow up and tracing details and, with the generous collaboration of local general practitioners, for forwarding questionnaires to parents; the parents for completing them; the Ordnance Survey and British Nuclear Fuels for making relevant information available to us; and many staff of the Medical Research Council Environmental Epidemiology Unit for their help, particularly Mick Merwood, Carol Wickham, and Paul Winter for computer analyses and Gill Strange for preparing the manuscript. Professor Geoffrey Rose kindly commented on an earlier version of the paper, and Professor Peter Smith and Allison Douglas helped with a sample check of the radiation dosimetry data. The study was approved by the British Medical Association ethical committee and the West Cumbria ethics of research committee and was supported partially by a grant from the Department of Health.

1 Gardner MJ. Review of reported increases of childhood cancer rates in the vicinity of nuclear installations in the UK. $\mathcal{R} R$ Statist Soc (A) 1989;152 307-25.

2 Black D. Investigation of the possible increased incidence of cancer in West Cumbria. London: HMSO, 1984.

3 Gardner MJ, Hall AJ, Snee MP, Downes S, Powell CA, Terrell JD. Methods and basic data of case-control study of leukaemia and lymphoma among young people near Sellafield nuclear plant in West Cumbria. Br Med $\mathcal{f}$ young people near
1990;300:429-34.
4 Breslow NE, Day NE. Stutistical methods in cancer research. Vol 1. The analysis of case-control studies. Lyon: International Agency for Research on Cancer, 1980:Chapters $V$ and VII

5 Anonymous. EGRET. Seattle: Statistics and Epidemiology Research Corporation, 1989.

6 Hall EJ. Radiobiology for the radiologist. Philadelphia: Harper and Row, 1978: Chapter 19.

7 Doll R. The epidemiology of childhood leukaemia. $f R$ Statist Soc $(A)$ 1989;152:341-51.

8 Ishimaru T, Ichimaru M, Mikami M. Leukaemia incidence among individuals exposed in utero, children of atomic bomb survivors and their controls, Hiroshima and Nagasaki, 1945-79. Hiroshima: Radiation Effects Research Foundation, 1981. (RERF Technical Report 11-81.)

9 Nomura T. Parental exposure to $x$ rays and chemicals induces heritable tumours and anomalies in mice. Nature 1982;296:575-7.

10 Committee on Medical Aspects of Radiation in the Environment. Investigation of the possible increased incidence of leukaemia in young people near Dounreay of the posstble increased incidence of leukaemia in young people near D
Nuclear Establishment, Caithness, Scotland. London: HMSO, 1988.

11 Committee on Medical Aspects of Radiation in the Environment. Report on the incidence of childhood cancer in the West Berkshire and North Hampshire area, in incidence of childhood cancer in the West Berkshire and North Hampshire area, in which are situated the Atomic Weapons Research Establishment, Alderna

12 Gardner MJ, Hall AJ, Downes S, Terrell JD. Follow up study of children born to mothers resident in Seascale, West Cumbria (birth cohort). Br Med $\mathcal{F}$ 1987;295:822-7.

13 Gardner MJ, Hall AJ, Downes S, Terrell JD. Follow up study of children born elsewhere but attending schools in Seascale, West Cumbria (schools cohort). Br.Med f 1987;295:819-22.

14 Beral V, Inskip H, Fraser P, Booth M, Coleman D, Rose G. Mortality of employees of the United Kingdom Atomic Energy Authority, 1946-1979. BrMed f 1985;291:440-7.

15 Beral V, Fraser P, Carpenter L, Booth M, Brown A, Rose G. Mortality of employees of the Atomic Weapons Establishment, 1951-82. Br Med $\mathcal{F}$ 1988;297:757-70.

16 Kinlen LJ. The relevance of population mixing to the aetiology of childhood leukaemia. In: Crosbie WA, Gittus JH, eds. Medical response to effects of leukising radiation. London: Elsevier, 1989:272-8.

17 Cook-Mozaffari P, Darby S, Doll R. Cancer near potential sites of nuclear installations. Lancet 1989;1i:1145-7.

18 International Commission on Radiological Protection. Recommendations of the International Commission on Radiological Protection. Oxford: Pergamon Press, 1966. (ICRP Publication Number 9.)

19 National Radiological Protection Board. Interim guidance on the implications of recent revisions of risk estimates and the ICRP 1987 Como statement. London: HMSO, 1987:4. (NRPB-G59.)

20 National Radiological Protection Board. Radiation exposure of the UK population-1988 review. London: HMSO, 1989:86. (NRPB-R227.)

21 Smith PG, Douglas AJ. Mortality of workers at the Sellafield plant of British Nuclear Fuels. Br Med J 1986;293:845-54.

(Accepted 29 fanuary 1990)
MRC Environmental

Epidemiology Unit

(University of

Southampton),

Southampton General

Hospital, Southampton SO9 4XY

Martin J Gardner, PHD, professor of medical statistics

Andrew J Hall, MRCP, epidemiologist

Michael P Snee, FRCR, radiotherapist

Susan Downes, BSC, research assistant

Caroline A Powell, MSC, research assistant

\section{West Cumbria Health} Authority, West

Cumberland Hospital, Whitehaven, Cumbria CA28 8JG

John D Terrell, FFCM, former district medical officer

Correspondence to: Professor Gardner.

BrMed F 1990;300:429-34

\title{
Methods and basic data of case-control study of leukaemia and lymphoma among young people near Sellafield nuclear plant in West Cumbria
}

\author{
Martin J Gardner, Andrew J Hall, Michael P Snee, Susan Downes, Caroline A Powell, \\ John D Terrell
}

\section{Abstract}

Objective-To examine whether the observed excess of childhood leukaemia and lymphoma near the Sellafield nuclear plant is associated with established risk factors or with factors related to the plant.

Design-A case-control study.

Setting - West Cumbria health district.

Subjects -52 Cases of leukaemia, 22 of nonHodgkin's lymphoma, and 23 of Hodgkin's disease occurring in people born in the area and diagnosed there in 1950-85 under the age of 25 and 1001 controls matched for sex and date of birth taken from the same birth registers as the cases.

Main outcome measures-Antenatal abdominal $x$ ray examinations, viral infections, habit factors, proximity to and employment characteristics of parents at Sellafield.

Results - Ascertainment of cases through multiple sources was as complete as possible, and the diagnosis was established for nearly all cases from hospital records and by independent pathological review when suitable material $(60 \%$ (58) of cases) was available. Identification and tracing of the parents of cases and controls enabled questionnaires to be forwarded to $730(66 \%)$, and $467(64 \%)$ of the questionnaires were returned completed. Obstetric records were located for $481(44 \%)$ of the relevant births, more frequently in recent years. Linkage of study subjects to the Sellafield workforce file enabled dates of employment and records on external doses of whole body ionising radiation to be obtained. Concordance of information from duplicate sources (when available) was reasonably high with no indications of bias.

Conclusion-Overall the collected data were sufficiently reliable for detailed analysis and careful interpretation.

\section{Introduction}

In November 1983 a Yorkshire Television programme (Windscale: the Nuclear Laundry) suggested that there was an excess incidence of childhood leukaemia and other cancers in the village of Seascale and some neighbouring areas close to the Sellafield nuclear site on the coast of Cumbria. The Black committee (of which MJG was a member) was set up to investigate this suggestion and made recommendations for four epidemiological studies related to childhood cancer in West Cumbria. ${ }^{1}$ Three of these, two reporting the occurrence of cancer among children born or attending 